\title{
DRY MATTER PARTITIONING DIFFERENCES BETWEEN SHOOTS AND ROOTS IN TWO CONTRASTING GENOTYPES OF ORCHIDS AND THEIR RELATIONSHIP WITH ENDOGENOUS LEVELS OF AUXINS, CYTOKININS AND ABSCISIC ACID
}

\author{
LÁZARO E. P. PERES ${ }^{1}$, NIDIA MAJEROWICZ² E GILBERTO B. KERBAUY ${ }^{3}$ \\ Departamento de Botânica, Universidade de São Paulo - USP Caixa Postal 11461， 05422-970, São \\ Paulo, SP, Brazil
}

\begin{abstract}
Epiphytic orchids have been considered an interesting model for plant development and may have unusual features related to the hormonal control of shoot and root growth. In the present experiment we have studied two genotypes of Catasetum fimbriatum Lindl. (Orchidaceae) with an inverse pattern of shoot and root dry matter accumulation. Whereas the CFC1 genotype directs $60 \%$ of dry matter towards the shoot system, this same amount is directed towards the root system in the CFC4 genotype. Differences in the endogenous content of cytokinins, IAA and ABA, as well as differences in IAA conjugation and oxidation in shoots and roots were observed in the two genotypes. These differences were correlated with their dry matter partitioning patterns. Thus, the genotype that directed $60 \%$ of dry matter towards the root system showed a 20 -fold higher auxin accumulation in those organs, while the one that accumulated $60 \%$ of dry matter in the shoots showed a 10-fold higher cytokinin accumulation in this plant part. Based on the well established information about auxin and cytokinin biosynthesis, conjugation, oxidation, transport, and effect on organ growth, we have presented an integrative working hypothesis to interpret the data obtained in this study. This working hypothesis may also account for the understanding of the complex relationships involving the hormonal control of the relative growth of shoots and roots in other plant models.
\end{abstract}

ADDITIONAL INDEX TERMS: epiphytes, development, in vitro culture, orchids, plant hormones

ABBREVIATIONS: [9R]iP, isopentenyladenosine; [9R]Z, zeatin riboside; ABA, abscisic acid; Ck(s), cytokinin(s); DW, -dry weight; ELISA, enzyme linked immuno sorbent assay; FW, fresh weight; HPLC, high performance liquid chromatography; IAA, indole-3-acetic acid; iP, isopentenyladenine; Z, -zeatin.

Received: 15/01/01 - Accepted: 27/08/01

1. Eng. Agr., Dr., Professor Doutor - Escola Superior de Agricultura Luiz de Queiroz - E-mail: lazaropp@esalq.usp.br

2. Bióloga, Dr., Professor Adjunto - Universidade Federal Rural do Rio de Janeiro- E-mail: nidia@ ufrrj.br

3. Biólogo, Dr., Professor Titular - Universidade de São Paulo - E-mail: gbtkerba@ib.usp.br 


\title{
DIFERENÇAS NA PARTIÇÃO DE MATÉRIA SECA ENTRE OS CAULES E RAÍZES EM DOIS GENÓTIPOS CONTRASTANTES DE ORQUÍDEAS E SUA RELAÇÃO COM OS NÍVEIS ENDÓGENOS DE AUXINAS, CITOCININAS E ÁCIDO ABSCÍSICO
}

\begin{abstract}
RESUMO - As orquídeas epífitas são consideradas modelos interessantes de desenvolvimento vegetal e possivelmente possuem características incomuns relacionadas ao controle hormonal do crescimento de caules e raízes. No presente experimento, estudaram-se dois genótipos de Catasetum fimbriatum Lindl. (Orchidaceae) com padrões inversos de acumulação de matéria seca nos caules e nas raízes. Enquanto o genótipo CFC1 direcionou 60\% de sua matéria seca para o sistema caulinar, essa mesma quantidade foi direcionada para o sistema radicular no genótipo CFC4. Foram observadas diferenças significativas no nível endógeno de citocininas, AIA e ABA, assim como na conjugação e degradação oxidativa de AIA nos caules e nas raízes dos dois genótipos. Essas diferenças tiveram uma boa correlação com os padrões de partição de matéria seca. Desse modo, o genótipo que direcionou $60 \%$ da matéria seca para as raízes mostrou uma acumulação de auxina 20 vezes maior nesses órgãos, ao passo que aquele que acumulou $60 \%$ da matéria seca nos caules mostrou uma acumulação de citocininas dez vezes maior nessas partes do vegetal. Com base em estudos bem estabelecidos na literatura sobre a biossíntese, conjugação, oxidação, transporte e efeitos de auxina e citocininas, elaborou-se uma hipótese integrativa para a interpretação dos resultados obtidos no presente experimento. Essa hipótese poderá também contribuir para um melhor entendimento das complexas interrelações envolvendo o controle hormonal do crescimento relativo dos caules e raízes em outros modelos vegetais.
\end{abstract}

TERMOS ADICIONAIS PARA INDEXAÇÃO: cultura in vitro, desenvolvimento, epífitas, hormônios vegetais, orquídeas

\section{INTRODUCTION}

Epiphytes have been considered as an interesting model for plant development and metabolic studies. In some extreme cases, epiphytic species can be represented by both shootless orchids (e.g. Campylocentrum) and rootless bromeliads (e.g. Tillandsia) (Peres et al., 1997). Among the epiphytic orchids, Catasetum fimbriatum has been shown to be suitable for physiological and biochemical experiments. It can be easily propagated through in vitro root tip culture (Kerbauy, 1984) allowing production of genetically uniform plants. Taking advantage of its genetic uniformity and the in vitro culture controlled environment, micropropagated Catasetum plants have been used for the study of sugars (Vaz et al., 1998), hormones (Peres et al., 1999) and nitrogen metabolism (Majerowicz et al., 2000). The regeneration of Catasetum plants from root tips involves an uncommon root-to-shoot meristem conversion (Kraus and Monteiro, 1989), which proved to be a novel and exclusive model for organogenetic competence studies (Colli and Kerbauy, 1993; Kerbauy and Colli, 1997; Peres and Kerbauy, 1999).

Shoot and root organs have coordinated and complementary functions in plant development. Catasetum shoot and root development presents some features that are not found in traditional plant models. Catasetum shoots are storage-like organs, named pseudobulbs, and therefore they are thought to be strong sinks. As many others epiphytic orchids, Catasetum has agravitropic, green and photosynthetic roots, which under certain conditions, may function as an assimilate source for negatively the whole plant. Furthermore, Catasetum has also negative geotropic roots that form trash-baskets used to capture litter and other organic debris (Benzing, 1996). In light of the fact that sink relationships and relative growth of 
shoots and roots may be controlled by hormones (Klee and Estele, 1991; Davies, 1995), it would be interesting to use Catasetum for such studies. However, as Catasetum is a non-domesticated allogamous plant, its seedlings are extremely variable and may not be suitable for use in controlled physiological experiments. To overcome this problem a good approach would be the selection of experimental plant material from single clones (Burr \& Tinus, 1996).

The aim of this work was to investigate whether the differences in dry matter partitioning between shoots and roots of Catasetum fimbriatum could be explained by the endogenous hormone levels of these organs, considering the effects of hormones in shoot and root growth. Thus, in the present work we evaluated the shoot and root growth differences in two contrasting clones of $C$. fimbriatum and the endogenous levels of IAA, $\mathrm{ABA}$ and cytokinins in these organs.

\section{MATERIALS AND METHODS}

\section{Plant Material}

Seedlings of Catasetum fimbriatum (Morren) Lindl. were asymbiotically obtained (Colli and Kerbauy, 1993) and micropropagated through either root tip segments (Kerbauy, 1984) or etiolated shoot segments induced in the dark (Kerbauy et al., 1995). Plant populations micropropagated from each isolated seedling consisted of genetically homogenous genotypes of C. fimbriatum named CFC1, CFC2, ... CFCn, which have been maintained in our lab since 1993. Both methods of micropropagation used are based on direct plant regeneration, i. e. without callus stage, in hormone free-media and using meristematic explants, so as to ensure the genetic integrity of these genotypes. Two genotypes, $\mathrm{CFC} 1$ and $\mathrm{CFC} 4$, presented remarkable differences related to their shoot and root growths (Table 1), and therefore were chosen for the present study. Vacin and Went (1949) modified medium without hormones (Peres et al., 1999; Peres and Kerbauy, 1999) was used for plantlet incubation in all treatments. Erlenmeyer flasks were filled with $80 \mathrm{~mL}$ of culture medium, and 9 to 15 explants were inoculated in each one. Cultures were maintained at $25 \pm 2{ }^{\circ} \mathrm{C}$ with $16 \mathrm{~h}$ fluorescent light (Dayhight) at $40 \mu \mathrm{mol} \mathrm{m} \mathrm{m}^{-2}$. Shoots (pseudobulbs + leaves) and roots fresh and dry matter were determined at the beginning of the experiment and after $60^{\text {th }}$ day of incubation; each treatment consisted of three replicates. For dry matter measurements shoots and roots were dried separately for $48 \mathrm{~h}$ at 60 ${ }^{\circ} \mathrm{C}$, and then weighed. For hormonal analysis, plants cultivated in basal medium for 60 days also had their shoots and roots separated.

TABLE 1 - Dry matter partitioning of two genotypes of $C$. fimbriatum at the beginning of the experiment and after a 60 -day growth period*.

\begin{tabular}{lllll}
\hline Beginning & \multicolumn{3}{c}{ dry weight $(\mathrm{mg})$} \\
\hline Genotypes & Shoot & Root & Total & $\begin{array}{l}\text { Ratio } \\
\text { Shoot per } \\
\text { Total }\end{array}$ \\
\hline CFC1 & $3.6 \pm 0.5 \mathrm{a}$ & $2.1 \pm 0.3 \mathrm{a}$ & $5.7 \pm 0.7 \mathrm{a}$ & $0.63 \pm 0.02 \mathrm{a}$ \\
CFC4 & $1.9 \pm 0.2 \mathrm{~b}$ & $2.9 \pm 0.3 \mathrm{a}$ & $4.8 \pm 0.3 \mathrm{a}$ & $0.41 \pm 0.03 \mathrm{~b}$ \\
\hline
\end{tabular}

\begin{tabular}{lllll}
\hline After 60 days & \multicolumn{4}{c}{ dry weight $(\mathrm{mg})$} \\
\hline Genotypes & Shoot & Root & Total & Ratio \\
& & & & Shoot per Total \\
\hline CFC1 & $13.8 \pm 1.4 \mathrm{a}$ & $10.2 \pm 1.2 \mathrm{a}$ & $24.1 \pm 2.5 \mathrm{a}$ & $0.58 \pm 0.01 \mathrm{a}$ \\
CFC4 & $7.9 \pm 0.8 \mathrm{~b}$ & $13.0 \pm 1.4 \mathrm{a}$ & $20.9 \pm 1.5 \mathrm{a}$ & $0.39 \pm 0.04 \mathrm{~b}$ \\
\hline
\end{tabular}

*Plants were incubated on a modified Vacin and Went (1949) supplied with $\mathrm{NO}_{3}{ }^{-}$and $\mathrm{NH}_{4}{ }^{+}$at 2:3 ratio $(6 \mathrm{mM}$ of total nitrogen). Each value represents the mean $\pm \mathrm{SE}$ $(\mathrm{n}=27)$. Mean values followed vertically by the same letter are not significant at $P<0.05$ by Student's t-test.

\section{Endogenous levels of auxins (free and conjugated), abscisic acid and cytokinins}

The endogenous hormonal levels were measured using $1 \mathrm{~g}$ of fresh tissue. The IAA, ABA, $\mathrm{Z},[9 \mathrm{R}] \mathrm{Z}, \mathrm{iP}$ and $[9 \mathrm{R}] \mathrm{iP}$ quantification was based on an indirect ELISA with previous purification of 
the extracts in reverse-phase HPLC as described previously (Peres et al., 1997; Zaffari et al., 1998). This method allowed the determination of the three hormonal classes in the same extract. For determination of conjugated auxins, their corresponding HPLC fractions were submitted to alkaline hydrolysis $\left(7 \mathrm{M} \mathrm{NaOH}\right.$ at $100{ }^{\circ} \mathrm{C}$ under $\mathrm{N}_{2}$ for $3 \mathrm{~h}$ ). After adjusting the $\mathrm{pH}$ to 2.5 with $\mathrm{HCl}$, the resulting free-IAA was extracted with ether three times. The fractions with ether were reduced to dryness in a Speed-Vac concentrator and then methylated with ethereal diazomethane. The measurements of the resulting free-IAA were carried out by ELISA with anti-IAA antibodies as previously described (Peres et al., 1997).

\section{Enzymatic oxidation of IAA}

For each extract, 1-2 g (FW) plant tissue were ground in $1 \mathrm{~mL}$ of cold ultra-pure water (milliQ ${ }^{\mathrm{TM}}$ ) as described by Saleh (1981). The homogenate was centrifuged $(30,000 \mathrm{x} \mathrm{g}, 30 \mathrm{~min})$ and then activated charcoal was added to the resulting supernatant. After clearing, the filtered supernatant was used as the enzyme source. The whole procedure was performed at $4{ }^{\circ} \mathrm{C}$. For the enzymatic destruction of IAA, $0.5 \mathrm{~mL}$ of the crude enzyme preparation was added to a mix of $1 \mathrm{~mL}$ acetate buffer $(0.2 \mathrm{M}) \mathrm{pH} 3.5,1 \mathrm{~mL} \mathrm{MnCl}_{2}(0.2$ $\mathrm{mM}), 1 \mathrm{~mL}$ 2,4-dichlorophenol $(0.2 \mathrm{mM}), 1 \mathrm{~mL}$ IAA $(0.2 \mathrm{mM})$, and $0.5 \mathrm{~mL}$ ultra-pure water. The tubes were incubated in water bath at $35{ }^{\circ} \mathrm{C}$ for 80 min. After these procedures, three fractions of 0.3 $\mathrm{mL}$ were collected and the reactions were terminated by the addition of $1 \mathrm{~mL}$ of modified Salkowski reagent (Gordon and Weber, 1951). The color was allowed to develop at room temperature for $1 \mathrm{~h}$, and the absorbance was measured at 530 $\mathrm{nm}$. The enzyme activity was expressed as nmol of IAA destroyed per hour per $\mu \mathrm{g}$ of protein in the extract. Protein was determined according to Bradford (1976) and BSA was used as the standard.

\section{Statistical analysis}

Hormone levels and IAA enzymatic destruction were measured four times in each treatment and standard errors were calculated. The dry and fresh matter were measured in 3 flasks per treatment with 9 plants each. From these parameters, the Student's t-test was performed and comparisons between means were made.

\section{RESULTS}

\section{Growth and dry matter partitioning in CFC1 and CFC4 genotypes}

Although $\mathrm{CFC1}$ and $\mathrm{CFC} 4$ plants have been produced and maintained in vitro under the same nutritional and environmental conditions, these genotypes showed significant differences in shoots dry matter accumulation from the beginning of the experiment, reflecting their genetic differences (Table 1). Initial dry matter accumulation in shoots of CFC1 was higher than in CFC4 and persisted for during 60 days of incubation. In spite of greater shoot growth in the CFC1 genotype, dry matter values obtained for CFC1 and CFC4 plants as a whole (shoot + root) were not significantly different, suggesting the involvement of compensatory process. This compensatory process could be the root growth, for which CFC4 genotype had the greatest values in all measurements, although the difference was not significant. Thus, the prominent differences observed in shoot/total ratio between the two genotypes (Table 1) seem to be determined by the tendency of the CFC1 genotype to direct assimilates mainly towards the shoot system and CFC4 genotype towards the root.

\section{Endogenous hormones in shoot and root of CFC1 and CFC4 genotypes}

Remarkable differences in endogenous levels of IIA, ABA and CKs were observed 
between the two C. fimbriatum genotypes (Fig. 1). Comparing the two genotypes, it seems quite clear that $\mathrm{CFC} 1$ and $\mathrm{CFC} 4$ have inverse tendencies regarding IAA and Cks accumulation (Fig. 1). Whereas CFC1 shoot Cks level is significantly ( $\mathrm{P}$ $<0.001$ ) higher than in CFC4 shoots, the CFC4 root IAA content is significantly $(\mathrm{P}<0.001)$ higher than in CFC1 roots (Fig. 1). The CFC1 genotype also presented increased IAA contents in the shoots and higher Cks contents in the roots when compared to the corresponding CFC4 parts (Fig 1). As regards the ABA levels, although CFC4 shoots presented a higher $\mathrm{ABA}$ content than those of CFC1 roots did not show a significant difference (Fig. 1).

The most prominent differences in hormone contents between the two genotypes, which potentially could explain differences in shoot and root growth (Table 1), seems to be the Cks content in CFC1 shoots and the IAA level in CFC4 roots.

From the results shown in Figure 2, it can be seen that the high total Cks level of $\mathrm{CFC1}$ shoots was largely due to free-base cytokinins (iP and $\mathrm{Z}$ ). As a rule, the roots of both genotypes presented small amounts of all measured Cks, when compared to shoots. It is interesting to highlight that the CFC1 genotype presented increased levels of all cytokinins measured in shoots and roots, except for the [9R]Z in shoots and iP in roots, which were not significantly higher than the corresponding CFC4 levels.

\section{Auxin metabolism in the CFC1 and CFC4 genotypes}

Taking into account the differences found in IAA contents in CFC1 and CFC4 genotypes (Fig. 1), we addressed the question of whether these differences could be explained by auxin catabolism. According to the results reported in Table 2 it can be seen that the genotypes presented significant differences in the capacity for IAA oxidation but not for IAA conjugation. Moreover, the two mechanisms that may account for auxin inactivation were always higher in shoots than in roots for both genotypes (Table 2). As regards IAA oxidation capacity, the $\mathrm{CFC} 4$ genotype presented enhanced values in shoots and roots. The higher values if IAA oxidation shown by CFC4 were coincident with both lower and higher freeIAA contents in its shoots and roots, respectively (Table 2 and Fig. 1), which suggests that this mechanism is not necessarily linked to free auxin levels in this case. Considering the auxin conjugation capacity, we could not find significant differences between the genotypes. However, the auxin conjugation capacity presented an inverse correlation $(\mathrm{r}=-0,60)$ with free-IAA contents in shoots and roots of both genotypes. Thus, it is likely that lower IAA conjugation in CFC4 roots is responsible, at least in part, for the high free IAA is responsible, at least in part, for the high free-IAA levels detected in this organ (Fig. 1).

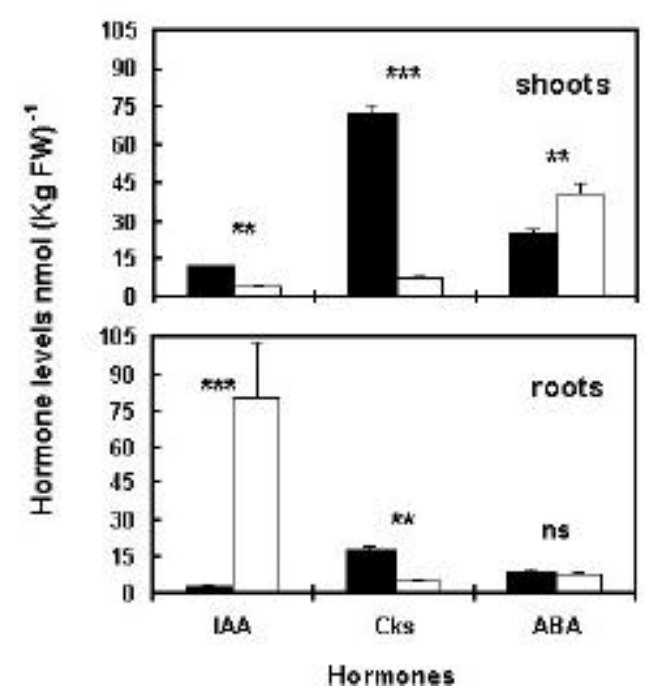

FIGURE 1 - IAA, Cks, and ABA contents in shoots and roots of $C$. fimbriatum genotypes CFC1 (closed bars) and CFC4 (open bars). Plants were cultured for 60 days on a modified Vacin and Went medium. Each column represents the mean $\pm \mathrm{SE}(\mathrm{n}=4)$. $\mathrm{FW}=$ fresh weight. $*, * *, * * *$ denote differences significant at the $\mathrm{P}=0.05(*), 0.01(* *)$ and $0.001(* * *)$ levels (Student's t-test), of contrasts between CFC1 and CFC4 genotypes; $\mathrm{ns}=$ non significant; $\mathrm{Cks}=\mathrm{iP}+$ $[9 \mathrm{R}] \mathrm{iP}+\mathrm{Z}+[9 \mathrm{R}] \mathrm{Z}$. 
TABLE 2 - IAA conjugation and enzymatic oxidation in shoots and roots of two $C$. fimbriatum genotypes.

\begin{tabular}{lcc}
\hline \multicolumn{3}{c}{ Shoots } \\
\hline Genotypes & IAA oxidized & IAA conjugated \\
CFC1 & $3.99 \pm 0.05 \mathrm{~b}$ & $3.87 \pm 0.72 \mathrm{a}$ \\
CFC4 & $18.9 \pm 0.55 \mathrm{a}$ & $2.14 \pm 0.39 \mathrm{a}$ \\
\hline & Roots & \\
\hline Genotypes & IAA oxidized & IAA conjugated \\
CFC1 & $1.85 \pm 0.63 \mathrm{~b}$ & $0.62 \pm 0.13 \mathrm{a}$ \\
CFC4 & $8.57 \pm 0.25 \mathrm{a}$ & $0.031 \pm 0.00 \mathrm{a}$ \\
\hline
\end{tabular}

Each value represents the mean $\pm \mathrm{SE}(\mathrm{n}=4)$. IAA oxidized was measured as nmol of IAA destroyed per hour per $\mu \mathrm{g}$ of protein. IAA conjugated was measured as nmol of released free IAA (after alkaline hydrolysis) per $g$ of fresh tissue. Mean values followed vertically by the same letter are not significant at $P<0.05$ by Student's t-test.

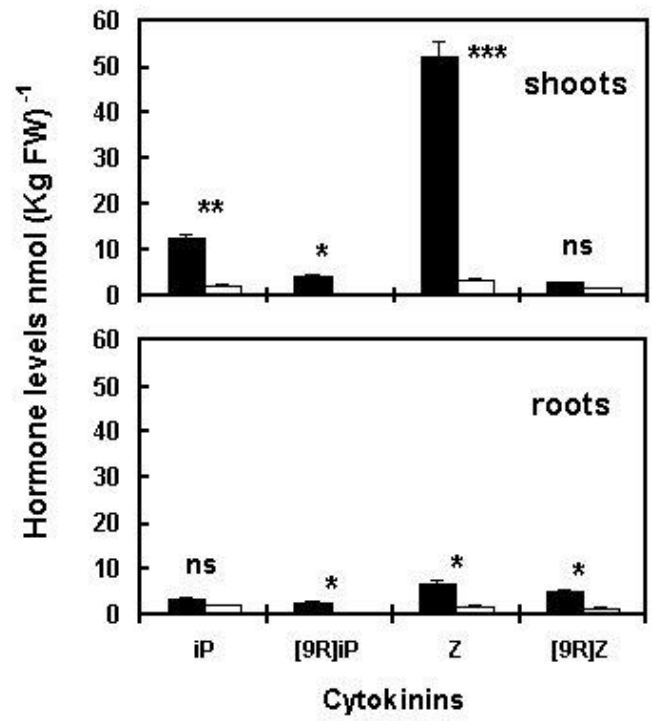

FIGURE 2 - iP, [9R]iP, Z, and [9R]Z content in shoots and roots of $C$. fimbriatum genotypes CFC1 (closed bars) and CFC4 (open bars). Otherwise as in Fig. 1.

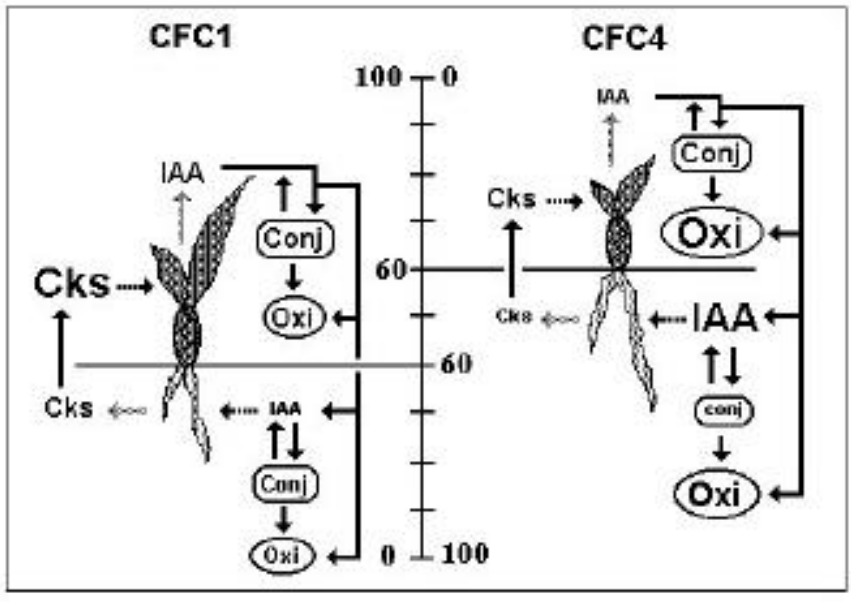

FIGURE 3 - A hypothesis which might account for the relationship between dry matter partitioning and endogenous hormonal levels ( and IAA metabolism) in two $C$. fimbriatum genotypes. Cytokinin metabolism was not considered in the present study. Hatched, solid, and interrupted arrows represent, respectively, hormone synthesis, transport/inactivation, and action. The symbols for cytokinins (Cks) and auxin (IAA), as well as, auxin conjugation (Conj.) and oxidation (Oxi) were represented by characters with proportional lengths to the dosages presented in Figures 1, 2 and Table 2. The central scale represents the percentage of dry weight (\% DW) accumulated by each genotype (Table 1). Note that in CFC1, $60 \%$ of DW is concentrated in shoots and that this same value is directed to the roots in the CFC4 genotype. The interactions represented in the figure are described in the text.

\section{DISCUSSION}

Two C. fimbriatum genotypes with inverse patterns of dry matter accumulation were studied. Whereas CFC1 genotype directed about $60 \%$ of its dry matter to shoots, CFC4 directed the same proportion towards the roots. Moreover, remarkable differences were observed in the endogenous content of CKs, IAA and ABA, as well as, in IAA metabolism in shoots and roots of these two genotypes, which can be well correlated with the differences in the dry matter partitioning . 
Plants with a somewhat elevated CK or IAA could present an imbalance between shoot and root growth. An example of this situation can be observed in transgenic plants expressing the Agrobacterium tumefaciens ipt gene, which present an enhanced $\mathrm{Ck}$ biosynthesis, and, in consequence, a high shoot formation and root initiation inhibition (Medford et al., 1989). Conversely, transgenic plants expressing A. tumefaciens auxin biosynthetic genes (iaaM and $i a a H$ ) tended to present substantial root initiation and lateral shoot formation inhibition (Klee et al., 1987). Arabidopsis mutants with high cytokinin or auxin accumulation (Chaudhury et al., 1993; Boerjan et al., 1995) also corroborate the assumption that these two hormone classes determine relative growth regulation of shoots and roots. A similar tendency was observed when the endogenous auxin and cytokinin levels were measured in Campylocentrum burchelli plants, a shootless orchid, and Tillandsia recurvata, a bromeliad with an extremely reduced root system (Peres et al., 1997).

The enhanced ABA levels in plant tissues induced through several type of stress, may also change the shoot/root ratio by inhibiting shoot growth more than root growth (Saab et al., 1990; Sharp et al., 1994). Through this perspective the highest ABA level found in CFC4 shoots may possibly be related to their poor shoot development. Under natural conditions, epiphytic orchids' aerial roots are permanently exposed to dry air, presenting an expressive root mass and relative high ABA levels (Peres et al., 1997). A requirement of $\mathrm{ABA}$ accumulation for the maintenance of root elongation under a low water potential condition was found by Sharp et al. (1994). However, under high water availability, high ABA levels could inhibit root growth (Pilet and Saugy, 1987). In the present study the diminished ABA content found in roots of both genotypes, which are cultivated in vitro under high water availability, could not be correlated with dry matter accumulation in those organs.
The overwhelming amount of evidences indicates that variation in the level of any hormone may affects the levels of others hormones (Saleh, 1981; Li et al., 1994; Zhang et al., 1995; Grossmann et al., 1996; Coenen and Lomax, 1997). In intact organs these interactions could be even more complex due to correlative processes. Thus, a hormone produced in a given organ could be transported to other plant parts where it stimulates growth, providing sites for biosynthesis, conjugation, oxidation, or transport of other hormones.

Based on information concerning auxin and cytokinin biosynthesis, conjugation, oxidation, transport and effects on organ growth (Davies, 1995; McGaw and Burch, 1995; Normanly, 1997; Jones and Schreiber, 1997) an attempt to interpret the results of the present study using an integrative work hypothesis (Fig. 3). It is postulated that roots are the main sites for cytokinin biosynthesis and exportation towards shoots, where they may promote growth. Conversely, shoots are considered as the main site for auxin biosynthesis, which may be inactivated by conjugation and/or oxidation, as well as exported towards roots. Shoot-derived auxin may promote root initiation and growth and may also suffer the effects of inactivation mechanism in roots.

This working hypothesis links amounts of Cks in CFC1 roots and shoots (Fig. 1; Fig. 3) with its increased shoot growth (Table 1; Fig. 3). Furthermore, well developed shoots of CFC1 may contribute to IAA accumulation in these organs (Fig. 1; Fig. 3). The relatively low auxin content of CFC1 roots seems to be correlated with the poor development of these organs (Table 1; Fig. 3) and may be a consequence of various auxin inactivation mechanisms found in both shoot and root of this genotype (Table 2; Fig. 3).

Contrarily, the CFC4 genotype presented substantialy lower root and shoot Cks levels (Fig. 1; Fig. 3), concomitantly with diminished shoot growth (Table 1; Fig. 3) and shoot auxin accumulation (Fig. 1; Fig 3). The low IAA level in CFC4 shoots may also be a consequence of inactivation processes in this organ (Table 2; Fig. 
3). Although CFC4 seems to have a high capacity for auxin oxidation in roots, its conjugation capacity has been shown to be very low (Table 2; Fig. 3). Therefore, it could be assumed that the low CFC4 root auxin conjugation contributes to a higher free IAA accumulation at these organs (Fig. 1; Fig. 3), leading to prominent growth (Table 1; Fig. 3). However, we cannot rule out the possibility of an elevated IAA biosynthesis in CFC4 roots. As epiphytic orchid roots have some shoot features, e. g. chlorophyll accumulation and negative geotropism (Benzing, 1996), it is not unrealistic to suggest that they may also have a considerable auxin biosynthetic capacity. De novo auxin biosynthesis in isolated roots of maize (Feldman, 1980; Ribaut et al., 1993) and Arabidopsis (Müller et al., 1998) has been documented. We reported earlier that isolated Catasetum roots accumulated both free and conjugated IAA, suggesting de novo auxin synthesis rather than a hydrolysis of preexisting conjugated forms (Peres and Kerbauy, 1999).

The low level of Cks accumulated in $\mathrm{CFC} 4$ roots suggests a reduction in Ck synthesis or its inactivation by glysoside-conjugation (McGaw and Burch, 1995) or oxidation (Hare and Van Staden, 1994; Jones and Schreiber, 1997). Previous studies with excised $C$. fimbriatum roots pointed to a decrease of CFC4 Cks biosynthetic capacity when compared with $\mathrm{CFC1}$ genotype (Peres and Kerbauy, 1999). According to these authors, after 10 days of in vitro culture the isolated roots of CFC4 and CFC1 accumulated, respectively, c.a. 200 and $500 \mathrm{nmol} \mathrm{K^{-1 }}$ (FW) of total cytokinins, with the riboside forms ([9R]Z and [9R]iP) as the main cytokinins accumulated (Peres and Kerbauy, 1999). Cytokinin ribosides have been considered transport forms (Letham and Palni, 1983), and their enhancement in cultured root segments was ascribed to an interruption in the translocation to shoots (Van Staden and Smith, 1978). The hydrolysis of these root-exported Cks ribosides in shoots could account for the high base-free Cks levels in shoot and their low levels in roots of CFC1 (Fig. 2). However, the CFC4 genotype presented relatively low levels of both ribosides and base-free Cks either in shoots and roots (Fig.
2). These results reinforce the hypothesis that the CFC4 genotype exhibits a reduced $\mathrm{Ck}$ biosynthetic capacity, rather than a higher $\mathrm{Ck}$ inactivation. Considering the integrative work hypothesis shown in Figure 3, the putative occurrence of reduced $\mathrm{Ck}$ biosynthesisin CFC4 roots may be sufficient to cause the other features presented by this genotype. In fact, one may expect that a genotype with a deficiency in root cytokinin production also may have a lower shoot growth and thus low shoot IAA production. To confirm the working hypothesis presented in Figure 3, further studies are necessary to assess parameters such as hormone transport, turn over and sensitivity in CFC1 and CFC4 shoots and roots.

In summary, the major findings reported here suggest that: (a) the CFC1 genotype tendency to direct dry matter towards shoots may be a consequence of its high Cks production by roots, which may account for shoot growth and its auxin production; (b) the inverse pattern of the CFC4 genotype, i. e., dry matter accumulation in roots, may be a consequence of the poor Cks production in this organ and consequently lower shoot growth and shoot-derived auxin production; (c) the high free IAA accumulation in CFC4 roots may be due to their relative low IAA conjugation capacity and/or their high auxin biosynthesis. An interesting approach to test these suggestions with Catasetum as well as with other models presenting differences in dry matter partitioning, should be to determine the pattern of expression of genes involved in $\mathrm{Cks}$ and auxin metabolism in shoots and roots. The recent isolation of genes for cytokinin conjugation (Martin et al., 1999), hydrolysis (Kristoffersen et al., 2000) and oxidation (Houba-Hérin et al., 1999), as well as, genes for auxin conjugation (Szerszen et al., 1994) and hydrolysis (Bartel and Fink, 1995) will provide futures implementation of such anapproach.

\section{ACKNOWLEDGMENTS}


We thank CAPES, FAPESP and CNPq for financial support and Dr. B. Sotta (Université Paris VI) for the donation of antibodies.

\section{REFERENCES}

BARTEL, B. \& FINK, G. R. ILR1, an amidohydrolase that releases active indole-3acetic acid from conjugates. Science, 268:1745-1748, 1995.

BENZING, D. H. Aerial roots and their environments. In: WAISER,Y; ESHEL, A. \& KAFKAFI, U (Eds). Plant roots the hidden half. New York, Marcel Dekker, 1996. p. 875894.

BOERJAN, W.; CERVERA, M-T; DELARVE, M.; BEECKMAN, T.; DEWITTE, W.; BELLINI, C.; CABOCHE, M.; Van ONCKELEN, H.; Van MONTAGU, M. \& INZÉ, D. Superroot, a recessive mutation in Arabidopsis, confers auxin overproduction. The Plant Cell, 7:1405-1419, 1995.

BRADFORD, M. M. A rapid and sensitive method for quantification of microgram quantities of protein utilizing the principle of protein-dye biding. Analytical Biochemistry, 72: 248-254, 1976.

BURR, K. E. \& TINUS, R. W. Use of clones increases the power of physiological experiments on coastal Douglas-fir. Physiologia Plantarum, 96:458-466, 1996.

CHAUDHURY, A. M.; LETHAM, D. S.; CRAIG, S. \& DENNIS, E. S. Amp 1 a mutant with high cytokinin levels and altered embryonic pattern, faster vegetative growth, constitutive photomorphogenesis and precocious flowering. The Plant Journal, 4: 907-916, 1993.

COENEN, C. \& LOMAX, T. L. Auxin-cytokinin interactions in higher plants: old problems and new tools. Trends in Plant Science, 2: 351356, 1997.
COLLI, S. \& KERBAUY, G. B. Direct root tip conversion of Catasetum into protocorm-like bodies. Effects of auxin and cytokinin. Plant Cell, Tissue and Organ Culture, 33:39-44, 1993.

DAVIES, P.J. The plant hormones: their nature, occurrence, and functions. In: DAVIES, P. J. (Ed.) Plant hormones: physiology, biochemistry and molecular biology. Dordrecht, Kluwer Acad. Publi., 1995. p. 1-12.

FELDMAN, L. J. Auxin biosynthesis and metabolism in isolated roots of Zea mays. Physiologia Plantarum, 49:145-150, 1980.

GORDON, S. A. \& WEBER, R. P. Colorimetric estimation of indoleacetic acid. Plant Physiology, 26:192-195, 1951.

GROSSMANN, K.; SCHELTRUP, F.; KWIATKOWSKI, J. \& GASPAR, G. Induction of abscisic acid is a common effect of auxin herbicides in susceptible plants. Journal of Plant Physiology, 149:475-478, 1996.

HARE, P. D. \& VAN STADEN, J. Cytokinin oxidase: biochemical features and physiological significance. Physiologia Plantarum, 91:128-136, 1994.

HOUBA-HÉRIN, N.; PETHE, C.; D’ ALAYER, J. \& LALOUE, M. Cytokinin oxidase from Zea mays: purification, cDNA cloning and expression in moss protoplasts. The Plant Journal, 17:615-626, 1999.

JONES, R. J. \& SCHREIBER, B. M. N. Role and function of cytokinin oxidase in plants. Plant Growth Regulation, 23:123-134,1997.

KERBAUY, G. B. Regeneration of protocorm-like bodies through in vitro culture of roots tips of Catasetum (Orchidaceae). Zeitschrift für Pflanzenphysiologie, 113: 287-291, 1984. 
KERBAUY, G. B \& COLLI, S. Increased conversion of apical root meristem of Catasetum fimbriatum into protocorm-like body through ethylene. Lindleyana, 12:59-63, 1997.

KERBAUY, G.B.; COLLI, S. \& MAJEROWICZ, N. Manutenção da atividade meristemática apical em caules de Catasetum (Orchidaceae) pelo etileno e escuro: implicações com uma nova estratégia de micropropagação. In: CONGRESSO BRASILEIRO DE FISIOLOGIA VEGETAL, 5, Lavras, 1995. Resumos. Lavras, SBFV/UFLA, 1995. P. 3.

KLEE, H. \& ESTELLE, M. Molecular genetic approaches to plant hormone biology. Annual Review of Plant Physiology and Plant Molecular Biology, 42:529-551, 1991.

KLEE, H.J.; HORSCH, R.B.; HINCHEE M.A.; HEIN M.B. \& HOFFMANN N.L. The effects of overproduction of two Agrobacterium tumefaciens T-DNA auxin biosynthetic gene products in transgenic petunia plants. Genes \& Development, 1:86-96, 1987.

KRAUS, J. E. \& MONTEIRO, W. R. Formation of protocorm-like bodies from root apices of Catasetum pileatum (Orchidaceae) cultivated in vitro. I. Morphological aspects, Annals of Botany, 64: 491-498, 1989.

KRISTOFFERSEN, P.; BRZOHATY, B.; HÖHFELD, I.; BAKO, L.; MELKONIAN, M. \& PALME, K. Developmental regulation of the maize Zm-p60.1 gene encoding a glucosidase located to plastids. Planta, 210:407-415, 2000.

LETHAM, D. S. \& PALNI, M. S. The biosynthesis and metabolism of cytokinins. Annual Review of Plant Physiology, 34:163-197, 1983.
LI, Y.; SHI, X.; STRABALA, T. J.; HAGEN, G. \& GUILFOYLE, T. J. Transgenic tobacco plants that overproduce cytokinins show increased tolerance to exogenous auxin and auxin transport inhibitors. Plant Science, 100:9-14, 1994.

MAJEROWICZ, N.; KERBAUY, G. B.; NIEVOLA, C. C. \& SUZUKI, R. M. Growth and nitrogen metabolism of Catasetum fimbriatum (Orchidaceae) grown with different nitrogen sources. Environmental and Experimental Botany, 44:195-206, 2000.

MARTIN, R. C.; MOK, M. C. \& MOK, D. W. S. Isolation of a cytokinin gene, ZOG1, encoding zeatin $O$-glucosyltransferase from Phaseolus lunatus. Proceedings of the National Academy of Sciences, USA, 96:284-289, 1999.

McGAW, B. \& BURCH, L. S. Cytokinin biosynthesis and metabolism. In: DAVIES, P. J. (Ed.) Plant hormones: physiology, biochemistry and molecular biology. Dordrecht, Kluwer Acad. Publi., 1995. p. 98 - 117.

MEDFORD, J. I.; HORGAN, R.; EL-SAWI, Z. \& KLEE, H. Alterations of endogenous cytokinins in transgenic plants using a chimeric isopentenyl transferase gene. The Plant Cell, 1: 403-413, 1989.

MÜLLER, A.; HILLEBRAND, H. \& WEILER, E.W. Indole-3-acetic acid is synthesized from L-tryptophan in roots of Arabidopsis thaliana. Planta, 206:362-369, 1998.

NORMANLY, J. Auxin metabolism. Physiologia Plantarum, 100: 431-442, 1997.

PERES, L. E. P. \& KERBAUY, G. B. High cytokinin accumulation following root tip excision changes the endogenous auxin-tocytokinin ratio during root-to-shoot conversion in Catasetum fimbriatum Lindl. (Orchidaceae). Plant Cell Reports, 18:1002-1006, 1999. 
PERES, L. E. P; MERCIER, H; KERBAUY, G. B. \& ZAFFARI, G. R. Níveis endógenos de AIA, citocininas e ABA em uma orquídea acaule e uma bromélia sem raiz, determinado por HPLC e ELISA. Revista Brasileira de Fisiologia Vegetal, 9:169-176, 1997.

PERES, L. E. P.; AMAR, S.; KERBAUY, G. B; SALATINO, A.; ZAFFARI, G. R. \& MERCIER, H. Effects of auxin, cytokinin and ethylene treatments on the endogenous ethylene and auxin-to-cytokinin ratio related to direct root tip conversion of Catasetum fimbriatum Lindl. (Orchidaceae) into buds. Journal of Plant Physiology, 155:551-555, 1999.

PILET, P.E. \& SAUGY, M. Effect of root growth of endogenous and applied IAA and ABA. A critical reexamination. Plant Physiology, 83:33-38, 1987.

RIBAUT, J. M.; SCHAERER, S. \& PILET, P. E., Deuterium-labelled indole-3-acetic acid neosynthesis in plantlets and excised roots of maize. Planta, 189:80-82, 1993.

SAAB, I. N.; SHARP, Q. E.; PRITCHARD, J. \& VOETBERG, G.S. Increased endogenous abscisic acid maintains primary root growth and inhibits shoot growth maize seedlings of low water potentials. Plant Physiology, 93: 1329-1336, 1990.

SALEH, N. A. The effects of kinetin on the indoleacetic acid level and indoleacetic acid oxidase activity in roots of young plants. Physiologia Plantarum, 51:399-401, 1981.

SHARP, R. E.; WU, Y.; VOETBERG, G. S.; SAAB, I. N. \& LENOBLE, M. E. Confirmation that abscisic acid accumulation is required for maize primary root elongation at low water potentials. Journal of Experimental Botany, 45:1743-1751, 1994.

SZERSZEN, J. B.; SZCAYGLOWSKI, K. \& BANDURSKI, R. S. iaglu, a gene from Zea mays involved in conjugation of growth hormone indole-3-acetic acid. Science, 265: 1699-1701, 1994.

VACIN, E. F. \& WENT, F. W. Some pH changes in nutrient solutions. Botanical Gazette, 110:605-617, 1949.

VAN STADEN, J. \& SMITH, A. R. The synthesis of cytokinins in excised roots of maize and tomato under aseptic conditions. Annals of Botany, 42:751-753, 1978.

VAZ, A. P. A.; KERBAUY, G. B. \& FIGUEIREDO-RIBEIRO, R. C. L. Changes in soluble carbohydrates and starch partitioning during vegetative bud formation from root tips of Catasetum fimbriatum (Orchidaceae). Plant Cell, Tissue and Organ Culture, 54: 105-111, 1998.

ZAFFARI, G. R; PERES, L. E. P. \& KERBAUY, G. B. Endogenous levels of cytokinins, IAA, ABA, and pigments in variegated somaclones of micropropagated banana leaves. Journal of Plant Growth Regulation, 17: 59-61, 1998.

ZHANG, R.; ZHANG, X.; WANG, J.; LETHAM, D. S.; McKINNEY, S. A. \& HIGGINS, T. J. V. The effect of auxin on cytokinin levels and metabolism in transgenic tobacco tissue expressing an ipt gene. Planta, 196: 84-94, 1995 